нормативно-правових актів, хоча, на думку автора таке врегулювання має бути на рівні окремого спеціального закону або ж, (тимчасово) на рівні імплементації відповідних положень у вже існуюче законодавство.

\title{
Література:
}

1. Лавренюк О. Ю. Кіберспорт і права інтелектуальної власності. National law journal: theory and practice. 2019. C. 81.

2. Толмачевська Ю. О., Ткалич М.O. Journal of the National Academy of Legal Sciences of Ukraine, 2018. Vol. 25, № 4. P. 90.

3. Наказ Міністерства молоді та спорту України від 16.09.2020 № 1557 / Міністерство молоді та спорту України. URL: https://zakon.rada.gov.ua/rada/show/v1557924-20

4. Наказ Міністерства молоді та спорту України від 26.01.2021 № 2/5.3/21 Про затвердження «Правил спортивних змагань 3 кіберспорту (електронного спорту) / URL: https://sport.gov.ua/storage/ app/sites/16/Sport/Pravyla_zmagan/2020/pravila-kibersport.pdf

5. UUOPEN 2019 WINTER CUP «Правила проведення змагань». 2019. / URL: https://esports.ua/tournaments/3-ukrainian-university-open2019-winter-cup/rules

DOI https://doi.org/10.30525/978-9934-26-040-7-42

\section{ПРОБЛЕМИ ПРАВОВОГО РЕГУЛЮВАННЯ СУСПІЛЬНИХ ВІДНОСИН У СФЕРІ УПРАВЛІННЯ ІДЕНТИФІКАЦІЙНИМИ ДАНИМИ}

\author{
Костенко О. В.
}

доктор філософії в галузі права,

в. о. завідувача науково-дослідної лабораторії теорії і права цифррових трансформачій

науково-дослідного иеентру цииррових трансформащій і права

Науково-дослідного інституту інформатики і права

Національної академії правових наук України м. Київ, Україна

Суспільство увійшло в епоху новітньої науково-технічної революції та економічної глобалізації. Одним із ключових елементів сучасних 
інформаційно-комунікаційних технологій передачі даних $є$ дані за якими можливо ідентифікувати суб'єктів за притаманними їм ідентифікаційними атрибутами. Вирішення проблеми управління ідентифікаційними даними $є$ базовою для сучасного розвитку електронної економіки. На сьогодні ряд міжурядових груп, держав, приватних міжнародних груп і комерційних структур активно вивчають питання управління ідентифікаційними даним, розробляють технічні стандарти і процедури правового забезпечення реалізації систем ідентифікації [1].

Україною також робить певні зусилля в напрямку технічної організації та розвитку процесів електронної ідентифікації, а саме: видано кілька регуляторних актів та розроблюється система електронної ідентифікації. Наразі ця система надає лише послуги перевірки цифрового підпису та підписання файлів цифровим підписом користувача без додаткових заходів ідентифікації підписантів. Фактично вона виступає в ролі транскодера між різноманітними системами ідентифікації, що створює низку суттєвих правових ризиків та правових невизначеностей.

Слід зазначити, що національне законодавство безперервно модернізується та поповнюється новими нормативно-правовими актами та дефініціями. Законотворці, намагаючись донести новизну законодавчих актів та наблизити правові норми до сучасних потреб суспільства, часто створюють дефініції у яких по-різному характеризують один і той самий об'єкт, що призводить до виникнення ситуації коли один термін в різних джерелах суттєво різниться за змістом. У ході розробки дефініції за допомогою різних прийомів викладу норм права, використання спеціальних термінів і стандартних мовних зворотів, правознавці намагаються досягти точності та визначеності формулювань, однак часто при цьому автори нормативно-правових актів не керуються вимогами до нормативних дефініцій, а спираються на ситуативність та суб’єктивність опису [2]. Так, наприклад, дефініція «автентифікація» має 13 інтерпретацій, «ідентифікація» - 12, «авторизація»-9, «ідентифікаційні дані»-6.

Крім того, така законодавча база в повній мірі не відображає реальний стан реагування держави на правопорушення із використанням ідентифікаційних та персональних даних, а також обмежена вкрай мінімізованими державними примусовими заходами. Таким чином, законодавство у сфері захисту персональних даних встановлює лише 5 видів правопорушень за скоєння яких наступає адміністративна відповідальність і лише одне правопорушення за скоєння якого тягне накладання штрафу [3]. 
Суттєвим ускладненням для функціонування систем управління ідентифікаційними даними стала відсутність єдиного класифікатора [4]. Для вирішення цієї проблеми доцільно розпочати формування класифікатора на основі документів, перелік яких визначено Законом України [5]. Окремо необхідно вирішити цілий комплекс технічних та юридичних питань, пов'язаних із застосуванням біометричних даних, які можливо використовувати як елементи ідентифікації особи.

Невизначеності також додає і низка різних схем ідентифікації суб'єктів за ідентифікаційними даними. Наразі в Україні функціонують такі схеми ідентифікації: «QsignID» (ідентифікатор - засоби кваліфікованого електронного підпису чи печатки), «BankID» (ідентифікатор електронна анкета $з$ ідентифікаційними даними користувача Системи BankID Національного банку України), «MobileID» (ідентифікатор ідентифікаційна телекомунікаційна картка, в якій зберігається особистий ключ кваліфікованого електронного підпису), «PasscardID» (ідентифікатор - безконтактний електронний носій, в якому зберігається особистий ключ кваліфікованого електронного підпису та ідентифікаційні дані власника) та «Мій ID» (проект, ідентифікатор - електронна анкета 3 ідентифікаційними даними власника облікового запису у Національній системі електронної ідентифікації «Мій ID»).

На нашу думку продовження створення Інтегрованої системи електронної ідентифікації за методом декодера або шлюзу між різноманітними інформаційними ресурсами та системами ідентифікаційних даних $є$ морально застарілим та містить багато юридичних ризиків.

Вектор всеохоплюючої цифровізації країни $є$ безумовно прогресивним та сучасним рухом у розбудові України. Досвід, отриманий у ході підготовки концепції Інтегрованої системи електронної ідентифікації, безперечно доцільно врахувати під час розробки та впровадженні сучасних правових механізмів управління ідентифікаційними даними та в подальшому створенні об'єднаної системи управління ідентифікаційними даними - «Полісистеми цифрової довіри України».

«Полісистема цифрової довіри України» (далі - Полісистема) - це багаторівнева соціотехніча система за допомогою якої значна кількість людей має можливість взаємодіяти з багатьма підсистемами та технічними пристроями. Полісистема, за допомогою сучасних технологічних рішень на основі штучного інтелекту, комплексу сучасних технічних стандартів, юридичних правил та норм, порядків і процедур перевірки ідентифікаційних даних, забезпечить тотожність ідентифікаційних даних з фізичною або юридичною особою, пристроєм або цифровим об'єктом ведення транзакцій, а також зберігання і захист ідентифікаційних даних [6]. Найголовнішим елементом Полісистема - це 
сучасна нормативно-правова база регулювання суспільних відносин у сфері управління ідентифікаційними даними, яка визначить права та обов'язки сторін, види порушень і відповідальність за їх скоєння, передбачить порядок страхування, забезпечить виконання зобов'язань сторін та відшкодування завданої шкоди тощо.

Також, Полісистема функціонуватиме на основі єдиного критерію ідентифікаційних даних, що міститься в іiі ядрі. Інформація, яка зберігається у відокремлених базах та реєстрах знеособлюється та прив'язується до єдиного особистого ідентифікаційного коду. Головною процедурою Полісистеми цифрової довіри стане процедура ідентифікації суб'єкта, яка чітко визначить ким насправді є особа, яка в даний момент часу надає запит на взаємодію із системою і проходить процедуру ідентифікації. Тобто, на відміну від сучасних систем із одноразовою ідентифікацією під час реєстрації, Полісистема застосовуватиме процедури ідентифікації кожного разу коли суб'єкт намагатиметься вчинити дії із юридично значимими інформаційними ресурсами. Такі процедури ідентифікації особи, здійснюватимуться із застосуванням програмних методів на основі штучного інтелекту без втручання людського фактора.

Так, запровадження «Полісистеми цифрової довіри України» дозволить:

- зменшити ризики пов'язані із електронною ідентифікацією особи, посвідченням автентичності, конфіденційністю, захищеністю даних, відповідальністю за заподіяну шкоду, забезпеченням виконання зобов'язань, юридичною відповідальністю та дотриманням правових норм національного законодавства;

- стати основою масштабного реінжинірингу всіх електронних ресурсів держави, модернізації інформаційно-комунікаційних систем та адміністративно-управлінських процесів;

- забезпечити трансформацію правової системи та правового регулювання сучасних суспільних відносин, а саме: створення нових напрямів законодавства та нормативно-правових актів, які регулюватимуть усі процеси управління ідентифікаційними даними та системою ідентифікації;

- сприятиме транскордонній ідентифікації та уніфікації права різних юрисдикцій.

\section{Література:}

1. Комиссия Организации Объединенных Наций по праву международной торговки. Рабочая группа IV (Электронная торговля) A_CN.9_WG.IV_WP.120_R 
URL:https://undocs.org/ru/A/CN.9/WG.IV/WP.120 (дата звернення 01.12.2020).

2. Селезньова О.М. Нормативні дефініції в інформативному праві / О.М. Селезньова / «Правова інформатика». - 2014 - № 1(41) - С. 23-29. (дата звернення 01.12.2020).

3. Кодекс України про адміністративні правопорушення: Закон України від 07.12.1984 р. № 8073-Х. / Законотворчість: база даних / Верховна Рада України URL: https://zakon.rada.gov.ua/laws/show/8073110\#Tеxt (дата звернення 02.12.2020).

4. Баранов О. А. Основи класифікації інформаційного законодавства. / О. А. Баранов // Правова інформатика. - 2006. - С. 25-32. http://ippi.org.ua/sites/default/files/06bokiz.pdf C-25-32 (дата звернення 01.12.2020).

5. Про Єдиний державний демографічний реєстр та документи, що підтверджують громадянство України, посвідчують особу чи іiі спеціальний статус: Закон України від 20.11.2012 р. № 5492-VI. / Законотворчість: база даних / Верховна Рада України URL: https://zakon.rada.gov.ua/laws/show/5492-17\#Text (дата звернення 02.12.2020).

6. Щедровицкий Г.П. Путеводитель по методологии организации, руководства и управления. URL: https://econ.wikireading.ru/47970 (дата звернення 02.12.2020).

DOI https://doi.org/10.30525/978-9934-26-040-7-43

\title{
УПРАВЛІННЯ СИСТЕМОЮ НАДАННЯ БЕЗОПЛАТНОЇ ПРАВОВОЇ ДОПОМОГИ: СУЧАСНИЙ СТАН ОРГАНІЗАЦЇ̈ ТА ПРАВОВОГО ЗАБЕЗПЕЧЕННЯ
}

\author{
Матюхіна Н. П. \\ доктор юридичних наук, професор, \\ професор кафедри адміністративного права \\ Національного юридичного університету імені Ярослава Мудрого \\ м. Харків, Україна
}

Ефективність функціонування системи надання безоплатної правової допомоги (БПД), якість правових послуг значною мірою 